\title{
Serological Diagnosis of Feline Coronavirus Infection by Immunochromatographic Test
}

\author{
Tomomi Takano and Tsutomu Hohdatsu
}

\begin{abstract}
The immunochromatographic assay (ICA) is a simple antibody-antigen detection method, the results of which can be rapidly obtained at a low cost. We designed an ICA to detect anti-feline coronavirus $(\mathrm{FCoV})$ antibodies. A colloidal gold-labeled recombinant $\mathrm{FCoV}$ nucleocapsid protein $(\mathrm{rNP})$ is used as a conjugate. The Protein A and affinity-purified cat anti-FCoV IgG are blotted on the test line and the control line, respectively, of the nitrocellulose membrane. The specific detection of anti-FCoV antibodies was possible in all heparin-anticoagulated plasma, serum, whole blood, and ascitic fluid samples from anti-FCoV antibody positive cats, and nonspecific reaction was not noted in samples from anti-FCoV antibody negative cats.
\end{abstract}

Key words Feline coronavirus, Immunochromatographic assay, Serological diagnosis

\section{Introduction}

Feline coronavirus (FCoV) is composed of nucleocapsid $(\mathrm{N})$ proteins, membrane $(\mathrm{M})$ proteins, and spike $(\mathrm{S})$ proteins. FCoV has been classified into serotypes I and II according to the amino acid sequence of its $S$ protein $[1,2]$. Both serotypes consist of two biotypes: feline infectious peritonitis virus (FIPV) and feline enteric coronavirus (FECV). FECV infection is asymptomatic in cats, whereas FIPV infection causes lethal disease: FIP [3]. FIPV (virulent $\mathrm{FCoV}$ ) has been proposed to arise from FECV (avirulent FCoV) due to a mutation [4-6]; however, the exact mutation and inducing factors have not yet been clarified.

It is normally comprehensively diagnosed based on the clinical condition, hematological profile, and results of $\mathrm{FCoV}$ genomic RNA and anti-FCoV antibody measurements in cats suspected of FIP [7]. An indirect immunofluorescence assay (IFA), and enzymelinked immunosorbent assay (ELISA) are used to measure FCoVantibodies. IFA and ELISA are highly sensitive and specific, but are cumbersome, expensive, and time-consuming. 
A simple and rapid method is necessary to prevent an epidemic of $\mathrm{FCoV}$ infection. A low-cost method is also needed to measure anti-FCoV antibodies in cats maintained in multi-cat environments. The most appropriate diagnostic method meeting these conditions may be immunochromatographic assay (ICA). The detection of anti-FCoV antibodies using ICA requires no special device or reagent, and the results can be simply and rapidly obtained. In this chapter, we describe our protocol for the preparation of the ICA to detect anti-FCoV antibodies using recombinant FCoV N protein [8].

\section{Materials}

\subsection{Recombinant FCoV N Protein (rNP)}

\subsection{Capture Agent}

\subsection{ICA Test Strip}

1. Plasmid DNA: pGEX4T-1 (GE Healthcare) with the $\mathrm{N}$ gene of the type I FIPV KU-2 strain (Gene Accession No. AB086881.1) (see Note 1).

2. Competent Escherichia coli, e.g., strain BL-21.

3. LB broth: $1.6 \%(\mathrm{w} / \mathrm{v})$ Bacto Tryptone, $1.0 \%(\mathrm{w} / \mathrm{v})$ Bacto Yeast Extract, and $0.5 \%(\mathrm{w} / \mathrm{v}) \mathrm{NaCl}$ in $\mathrm{ddH}_{2} \mathrm{O}$, and adjusted to $\mathrm{pH} 7.0$ with $5 \mathrm{~N} \mathrm{NaOH}$.

4. $100 \mathrm{mg} / \mathrm{ml}$ ampicillin sodium in water.

5. $100 \mathrm{mM}$ isopropyl $\beta$-D-L-thiogalactopyranoside (IPTG) in water.

6. $10 \mathrm{mg} / \mathrm{ml}$ lysozyme in water.

7. $100 \mathrm{mM}$ phenylmethylsulfonyl fluoride (PMSF) in methanol.

8. $1 \mathrm{mg} / \mathrm{ml} \mathrm{DNase} \mathrm{I} \mathrm{in} 0.15 \mathrm{M} \mathrm{NaCl}$.

9. $0.1 \mathrm{mg} / \mathrm{ml}$ sodium deoxycholate in water.

10. Elution buffer: $0.3 \%(\mathrm{w} / \mathrm{v})$ reduced glutathione in $0.1 \mathrm{M}$ Tris-HCl, $\mathrm{pH} 8.0$.

11. Sonicator.

1. $0.5 \mathrm{mg} / \mathrm{ml}$ purified IgG from serum of FCoV-infected cat (see Notes 2 and 3 ).

2. $2.0 \mathrm{mg} / \mathrm{ml}$ monoclonal antibody $(\mathrm{mAb}) \mathrm{YN}-2$ (anti-FCoV N protein; IgG2a) (see Note 4 ).

3. $0.1 \mathrm{mg} / \mathrm{ml}$ Protein A.

1. Sample pad and absorbent pad: C083 Cellulose Fiber Sample Pad Strips (Millipore).

2. Nitrocellulose membrane: Hi-Flow Plus 240 Membrane Cards (Millipore).

3. Automatic cutter, e.g., CM4000 (BioDot) or scissors.

4. Dispensing machine, e.g., XYZ3050 (BioDot) or fine-point brush. 


\subsection{Colloidal} Gold-Labeled rNP
1. Diluting/preserving solution: $20 \mathrm{mM}$ sodium tetraborate, $1 \%$ $(\mathrm{w} / \mathrm{v})$ bovine serum albumin $(\mathrm{BSA})$, and $0.1 \%(\mathrm{w} / \mathrm{v}) \mathrm{NaN}_{3}$ in water.

2. Colloidal gold solution $(40 \mathrm{~nm})$.

3. $10 \%(\mathrm{w} / \mathrm{v})$ BSA in water.

4. Borax containing $10 \% \mathrm{BSA}$.

\section{Methods}

\subsection{Preparation of $r N P$}

1. Incubate BL-21 cells containing pGEX4T- 1 with the $\mathrm{N}$ gene of the type I FIPV KU-2 strain overnight at $37{ }^{\circ} \mathrm{C}$ in $10 \mathrm{ml}$ of LB broth containing $100 \mu \mathrm{g} / \mathrm{ml}$ ampicillin (LB/AMP broth).

2. Dilute overnight cultures $1: 100 \mathrm{in} 100 \mathrm{ml}$ of fresh LB/AMP broth and grow to $\mathrm{OD}_{600}$ of $0.4-0.5$.

3. Induce expression of GST-tagged rNP by adding $100 \mu \mathrm{l}$ of $0.1 \mathrm{mM}$ IPTG to the culture.

4. Incubate for $24 \mathrm{~h}$ at $25^{\circ} \mathrm{C}$ in shaking incubator.

5. Centrifuge at $12,000 \times g$ for $15 \mathrm{~min}$ and resuspend the cell pellet in $30 \mathrm{ml}$ of PBS.

6. Add $0.8 \mathrm{ml}$ of $10 \mathrm{mg} / \mathrm{ml}$ lysozyme and $0.4 \mathrm{ml}$ of $100 \mathrm{mM}$ PMSF to the suspension and mix.

7. Incubate on ice for $20 \mathrm{~min}$.

8. Add $0.3 \mathrm{ml}$ of $0.1 \mathrm{mg} / \mathrm{ml}$ sodium deoxycholate.

9. Lyse bacterial cells by three $30 \mathrm{~s}$ pulses of sonication on ice using a sonicator.

10. Add $0.2 \mathrm{ml}$ of $1 \mathrm{mg} / \mathrm{ml}$ DNase I to the cell lysate and incubate for $30 \mathrm{~min}$ at $25^{\circ} \mathrm{C}$.

11. To remove bacterial debris, centrifuge cell lysate at $12,000 \times g$ for $15 \mathrm{~min}$ at $4{ }^{\circ} \mathrm{C}$.

12. Wash glutathione sepharose beads by adding $40 \mathrm{ml}$ of PBS per $6.7 \mathrm{ml}$ of original slurry of glutathione sepharose ( see Note 5 ).

13. Add supernatant to the washed glutathione sepharose beads, and rotate overnight at $4^{\circ} \mathrm{C}$.

14. Wash sepharose beads with bound GST-tagged rNP in PBS at for $5 \mathrm{~h}$ at $4{ }^{\circ} \mathrm{C}$ with rotation.

15. Spin down the beads at $700 \times g$ for $5 \mathrm{~min}$ at RT, and resuspend in $40 \mathrm{ml}$ of PBS per $6.7 \mathrm{ml}$ of original slurry.

16. Spin down the beads at $700 \times g$ for $5 \mathrm{~min}$ at RT. 


\subsection{Preparation of the ICA Test Strip}

17. Elute GST-tagged rNP from beads using $10 \mathrm{ml}$ of Elution buffer at RT, and $1 \mathrm{ml}$ of fractions $(0.2 \mathrm{ml} /$ tube $)$ are collected into test tubes (see Note 6 ) and analyzed by SDS-PAGE and Western immunoblotting, using standard procedures.

18. Eluted peak fractions (tube no. 18-22) are pooled and dialyzed against PBS using dialysis tubing for overnight.

The ICA test strip consists of three main components: a sample pad, nitrocellulose membrane, and absorbent pad (Fig. la, b).

1. Stick the sample pad and absorbent pad onto the nitrocellulose membrane using adhesive tape, overlapping by $3 \mathrm{~mm}$.

2. Cut this sheet into $2 \mathrm{~cm}$ strips using an automatic cutter or scissors.

3. Dispense 20-30 $\mu \mathrm{l}$ of protein A onto the test line of the nitrocellulose membrane using a dispensing machine or a fine-point brush (see Note 7).

4. Dispense 20-30 $\mu$ l of affinity-purified $\operatorname{IgG}$ from serum of FCoV-infected cat or mAb YN-2 onto the control line of the nitrocellulose membrane using a dispensing machine or a finepoint brush.

5. Dry the membrane for $30 \mathrm{~min}$ at room temperature and then cut into $0.5 \mathrm{~cm}$ strips using an automatic cutter or scissors.

1. Dilute $\mathrm{rNP}$ in PBS to $0.5 \mathrm{mg} / \mathrm{ml}$.

2. Add $30 \mu \mathrm{l}$ of the diluted $\mathrm{rNP}$ to $1 \mathrm{ml}$ of colloidal gold solution.

3. Stir well and incubate for $30 \mathrm{~min}$ at room temperature.

a

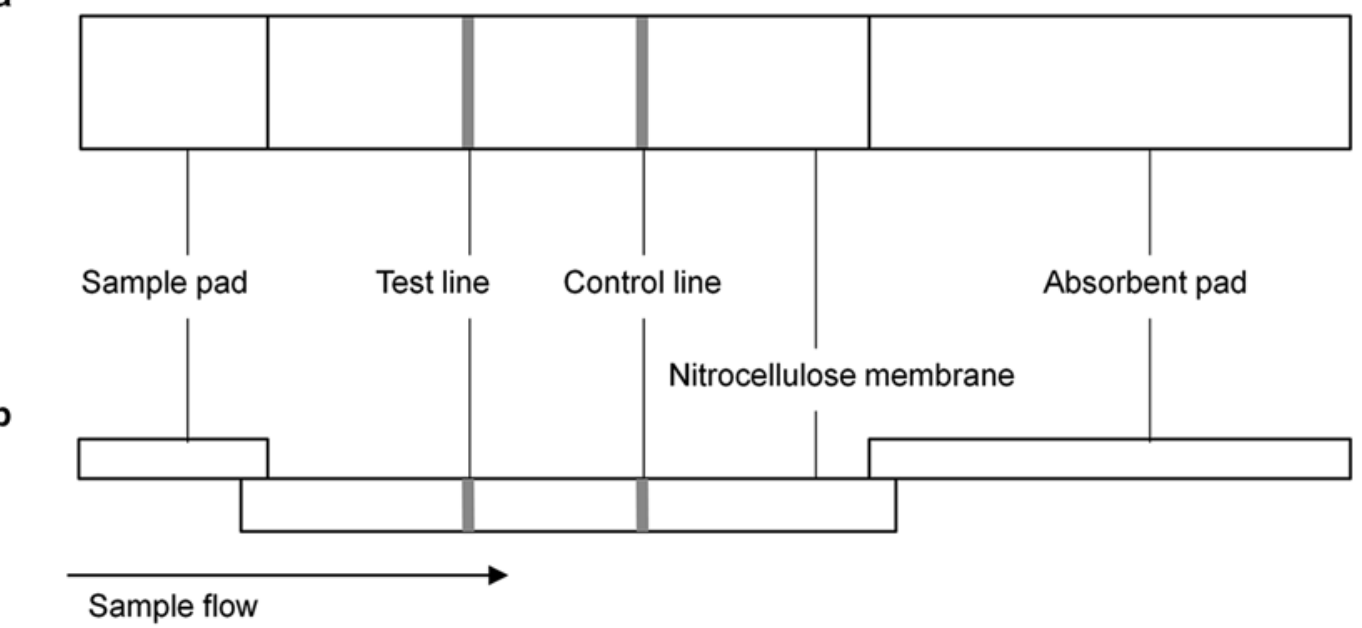

Fig. 1 Schematic diagrams of ICA test strip. (a) Top view and (b) Side view 
4. Add $100 \mu \mathrm{l}$ of $20 \mathrm{mM}$ Borax containing $10 \%$ BSA.

5. Incubate for $30 \mathrm{~min}$ at room temperature.

6. Centrifugation at $22,000 \times g$ for $10 \mathrm{~min}$ and resuspend the pellet in $0.75 \mathrm{ml}$ of $20 \mathrm{mM}$ Borax containing $10 \%$ BSA.

\subsection{Procedure for ICA Test}

A schematic of the principle of the ICA test is provided in Fig. 2a.

1. Dilute the sample (i.e., plasma, serum, and effusive fluid) 80 times with eluent solution ( see Note 8).

2. Mix $40 \mu \mathrm{l}$ of this dilution with $20 \mu \mathrm{l}$ of the colloidal goldlabeled rNP (from Subheading 3.3, step 6) in the well of a 96-well plate.

3. Insert the ICA test strip into the well of the 96-well plate and allow mixture to be absorbed (Fig. 2b).

4. The test line or/and control line will appear after $10 \mathrm{~min}$ at room temperature (Fig. 2c).

a

\begin{tabular}{cc}
\multicolumn{2}{c}{ Anti-FCoV N antibody } \\
\hline Positive sample
\end{tabular}
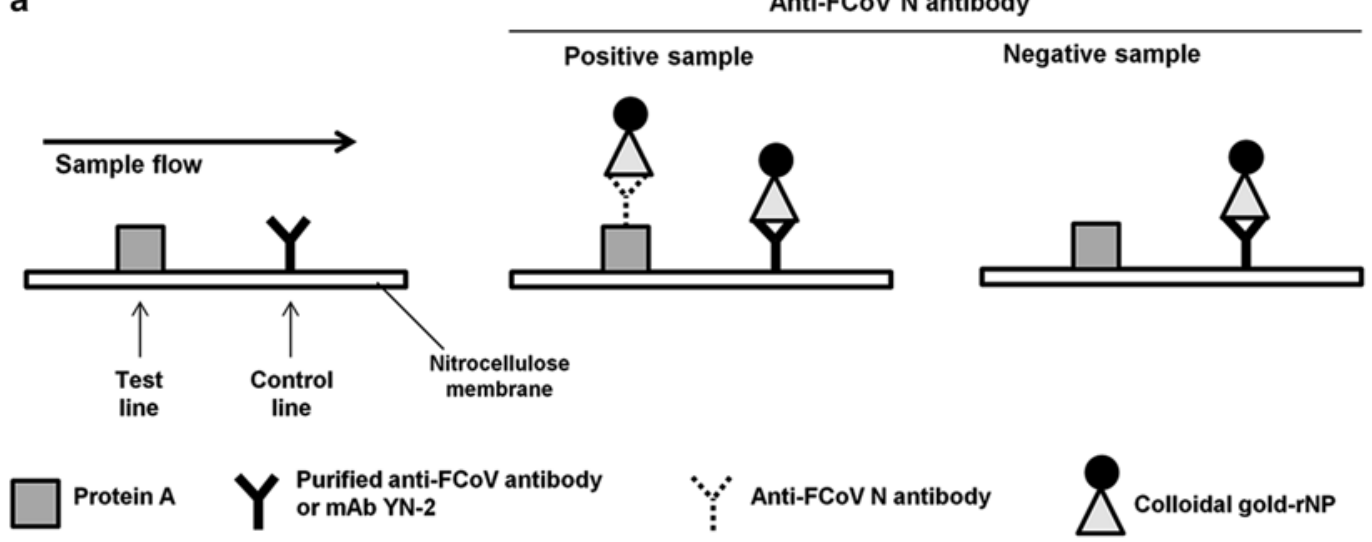

Negative sample

b

C
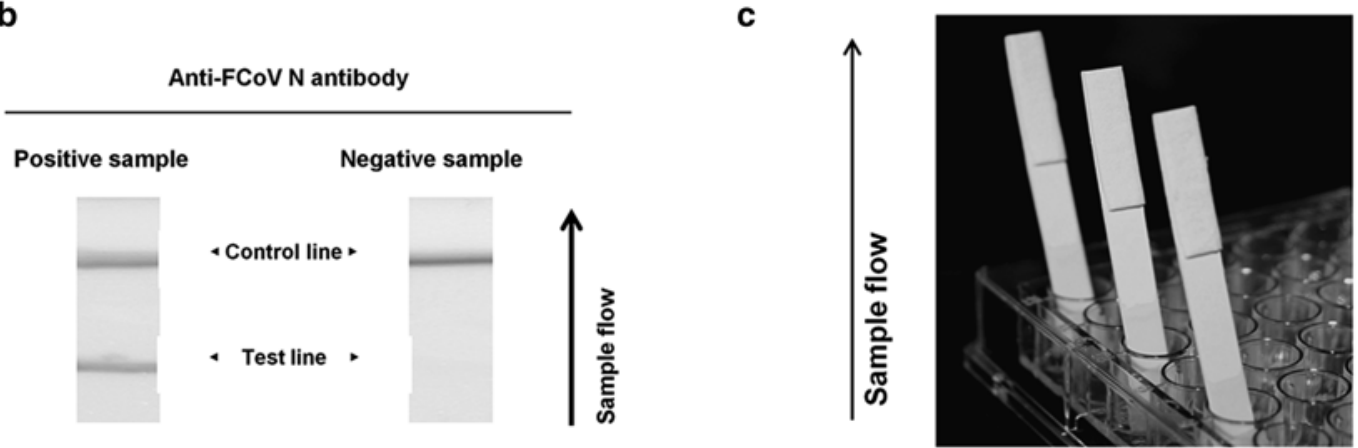

Fig. 2 Principle of the ICA test and example results. (a) Outline of the principle of anti-FCoV antibody detection. (b) The sample pad at the end of the ICA test strip is dipped in the sample mixture. (c) Typical positive and negative results. C: control line (mAb YN-2). T: test line (Protein A) 


\section{Notes}

1. Based on our experience, $\mathrm{N}$ protein is more efficiently expressed in E. coli than other structural proteins ( $\mathrm{S}$ protein and M protein) of $\mathrm{FCoV}$.

2. Feline $\operatorname{IgG}$ is isolated by affinity chromatography on a Protein G column.

3. Serum and plasma from FCoV-infected cats are good source of cat anti-FCoV IgG. However, large amount of serum and plasma are needed for developing ICA test. It is practically difficult to obtain large amounts of serum and plasma from FCoV-infected cats. Therefore, we recommend using antiFCoV mAb instead of cat anti-FCoV IgG.

4. The Hybridoma producing $\mathrm{mAb} Y \mathrm{~N}-2$ was prepared following the method reported by Hohdatsu et al. [1]. In our experience, the $\mathrm{mAb} Y \mathrm{~N}-2$ has a higher affinity for the colloidal goldlabeled $\mathrm{rNP}$ than other anti-FCoV $\mathrm{N}$ mAb (e.g., $\mathrm{mAb}$ E22-2).

5. Glutathione sepharose beads are just added to PBS and then they are ready to use.

6. GST-tagged rNP was eluted from the beads by drip-through at a constant flow $(2.0-3.0 \mathrm{ml} / \mathrm{min})$.

7. Generally, reagents are dispensed by the dispensing machine on a nitrocellulose membrane. However, this machine is very expensive. If you intend to develop an ICA kit on a trial basis, we recommend using a fine-point brush instead of the machine.

8. The specific detection of anti-FCoV antibodies was possible in all heparin-anticoagulated plasma, serum, whole blood, and ascitic fluid samples from anti-FCoV positive cats. On the other hand, the nonspecific test line formation was noted in EDTA- or sodium citrate-anticoagulated plasma of anti-FCoV negative cats.

\section{Acknowledgments}

We thank all the colleagues of our laboratory for assistance on ICA development. This work was in part supported by KAKENHI (Grants-in-Aid for Scientific Research (B), No. 25292183) from the Ministry of Education, Culture, Sports, Science, and Technology, and the Research Fund of Petience Medical Corporation. 


\section{References}

1. Hohdatsu T, Okada S, Koyama H (1991) Characterization of monoclonal antibodies against feline infectious peritonitis virus type II and antigenic relationship between feline, porcine, and canine coronaviruses. Arch Virol 117:85-95

2. Motokawa K, Hohdatsu T, Aizawa C et al (1995) Molecular cloning and sequence determination of the peplomer protein gene of feline infectious peritonitis virus type I. Arch Virol 140:469-480

3. Pedersen NC (2009) A review of feline infectious peritonitis virus infection: 1963-2008. J Feline Med Surg 11:225-258

4. Brown MA (2011) Genetic determinants of pathogenesis by feline infectious peritonitis virus. Vet Immunol Immunopathol 143:265-268
5. Chang HW, Egberink HF, Halpin R et al (2012) Spike protein fusion peptide and feline coronavirus virulence. Emerg Infect Dis 18:1089-1095

6. Chang HW, de Groot RJ, Egberink HF et al (2010) Feline infectious peritonitis: insights into feline coronavirus pathogenesis and epidemiology based on genetic analysis of the viral $3 \mathrm{c}$ gene. J Gen Virol 91:415-420

7. Addie D, Belák S, Boucraut-Baralon $\mathrm{C}$ et al (2009) Feline infectious peritonitis. ABCD guidelines on prevention and management. J Feline Med Surg 11:594-604

8. Takano T, Ishihara Y, Matsuoka M et al (2013) Use of recombinant nucleocapsid proteins for serological diagnosis of feline coronavirus infection by three immunochromatographic tests. J Virol Methods 196:1-6 